\title{
Historical Evolution of Skin Grafting-A Journey through Time
}

\author{
Michael Kohlhauser 1,2,*(D), Hanna Luze ${ }^{1,2}$, Sebastian Philipp Nischwitz ${ }^{1,2}$ (D) and Lars Peter Kamolz ${ }^{1,2}$ \\ 1 COREMED—Cooperative Centre for Regenerative Medicine, Joanneum Research Forschungsgesellschaft \\ mbH, 8010 Graz, Austria; hanna.luze@joanneum.at (H.L.); sebastian.nischwitz@joanneum.at (S.P.N.); \\ lars.kamolz@medunigraz.at (L.P.K.) \\ 2 Division of Plastic, Aesthetic and Reconstructive Surgery, Department of Surgery, Medical University of Graz, \\ 8036 Graz, Austria \\ * Correspondence: michael.kohlhauser@joanneum.at; Tel.: +43-316-876-6003
}

check for updates

Citation: Kohlhauser, M.; Luze, H.; Nischwitz, S.P.; Kamolz, L.P. Historical Evolution of Skin Grafting-A Journey through Time. Medicina 2021, 57, 348. https:// doi.org/10.3390/medicina57040348

Academic Editors: Rytis Rimdeika and Gadi Borkow

Received: 4 March 2021

Accepted: 2 April 2021

Published: 5 April 2021

Publisher's Note: MDPI stays neutral with regard to jurisdictional claims in published maps and institutional affiliations.

Copyright: (c) 2021 by the authors. Licensee MDPI, Basel, Switzerland. This article is an open access article distributed under the terms and conditions of the Creative Commons Attribution (CC BY) license (https:// creativecommons.org/licenses/by/ $4.0 /)$.
Abstract: Autologous skin grafting was developed more than 3500 years ago. Several approaches and techniques have been discovered and established in burn care since then. Great achievements were made during the 19th and 20th century. Many of these techniques are still part of the surgical burn care. Today, autologous skin grafting is still considered to be the gold standard for burn wound coverage. The present paper gives an overview about the evolution of skin grafting and its usage in burn care nowadays.

Keywords: skin grafting; skin transplantation; skin substitutes; history; burns

\section{Introduction}

The skin is not only the largest organ of the human body but also the first line of defense against harmful influences such as mechanical forces, microorganisms, or radiation. It maintains thermoregulation and fluid balance as well as acts as a sensory organ that is able to register pressure, temperature, and pain, due to specific receptors. The integrity of human skin plays an essential role in maintaining physiological homeostasis of the body. A large skin loss caused by e.g., burns, can cause a disturbance of this integrity [1,2]. To date, autologous skin grafting is commonly considered as the gold standard for the coverage of large skin defects. While the usage of meshed split thickness skin grafting is the best option for the treatment of extensive burns, unmeshed sheet grafting is used for small burns and in aesthetically important regions. Full-thickness skin grafting achieves the best aesthetic and functional results in burn injury reconstruction [3-5].

The origin of skin grafting can be traced back for more than 3500 years. Many techniques and adjustments have been established over time. This article gives an overview about the historical evolution of skin grafting, including the development of common techniques, and further explains their usage in burn care nowadays. In addition, the development and the usage of further established techniques are presented. Finally, the split-thickness skin graft associated donor site problems are analyzed, and solutions are discussed.

\section{The Origin of Skin Grafting}

Skin grafting was already practiced in the Egyptian Empire. This ancient skin graft technique was already taking place 1500 before Christ (BC) and was documented in an old papyrus role called "Ebert papyrus" [6]. According to the "Sushruta Samhita", one of the early texts of Ayurveda, skin grafting was also performed by the ancient Hindu more than 3000 years ago. Members of the Koomas Caste used subcutaneous fat and skin from the gluteal region as free skin graft [6-8]. In the 1st and 2nd century, Celsus and Galen used skin grafts to treat facial defects. Furthermore, Celsus developed a method to reconstruct the foreskin of Jewish men in historical Roman Empire [7]. During a long period, most of the knowledge was forgotten. For example, the earlier known techniques of free skin 
grafting got lost in the Middle Ages. The method seemed to be forgotten until the early 19th century. In 1804, Giuseppe Baroni demonstrated successful transplantations of free skin grafts in ram. Seventeen years later, the first verified successful nasal reconstruction by usage of free skin autografting was performed by Professor Bünger, which was inspired by the ancient Indian method [8-10].

In 1869, Jaques-Louis Reverdin, a Swiss surgeon, presented a successful experiment of free skin grafting $[6,7,9,11]$. By using the tip of a lancet, Reverdin harvested epidermal small bits from the arm of the patient and fixed them into the middle of wound with a diachylon bandage. Although the procedure is known as "Pinch Graft" today, Reverdin called his technique "Epidermic Grafting" [6,7]. In May 1870, Georg David Pollock was the first surgeon who performed a successful pinch graft in a burn victim case. His patient was an 8-year-old girl who suffered a large defect of her right thigh by severe burns $[6,7,12,13]$. Pollock transplanted two small pieces from the abdomen to the middle of the lower part of the defect. Three weeks later, a second series was transplanted into the wound. After 6 weeks, all grafts grew well and divided the defect into two parts. Two further pinch grafts, harvested from the abdomen, were successfully transplanted. Pollock also performed the first known allografts to a burned patient in combination with autologous pinch grafts. However, the allogeneic grafts did not grow and were gradually destroyed, but they seemed to stimulate the spontaneous healing of the autologous pinch grafts $[12,13]$.

\section{The Split-Thickness Skin Graft}

The history of split-thickness skin grafting dates back to the late 19th century. The earliest known split-thickness skin grafting method was developed by Ollier in 1872. His results revealed not only a faster healing but also less scar formation and therefore less scar contractures by covering the whole wound surface with skin grafts. Since these grafts included epidermis as well parts of the dermis, Ollier called his technique "dermoepidermic grafting" [6]. Prof. Carl Thiersch, chairman of the surgery department in Leipzig, presented his technique at the 15th Congress of German Surgical Association in $1886[6,14]$. His technique advised to cut the skin with a razor blade as thin as possible via sharp horizontal incisions to produce thin strips of epidermis, only including small parts of dermis $[6,7,15]$. Thiersch's technique obtained national publicity, which is known as "Thiersch Graft" [6]. Caused by the similarity of both discoveries, the method is also known as "Ollier-Thiersch graft". In 1929, Blair and Brown presented their method of "split skin grafts" of intermediate thickness. These grafts differ from "Ollier-Thiersch graft" in regard of the thickness due to included layers of dermis. While Ollier and Thiersch advised to include only little more than the epithelial layer, the split skin grafts of intermediate thickness also included an appreciable amount of the dermal layer. The idea was to preserve the advantages of both, the "Ollier-Thiersch graft", as well those of the full-thickness skin graft [16]. In 1941, Earl C. Padgett, an American surgeon, developed a new method of split-thickness skin grafting by using a manual dermatome. The "three-quarter"-thickness skin graft demonstrated good graft take, and the dermatome enabled the possibility of new skin donor sites, which were not available by free hand skin grafting methods [17].

The current STSG classification is based according to their thickness into thin STSGs (0.15 to $0.3 \mathrm{~mm})$, intermediate STSGs (0.3 to $0.45 \mathrm{~mm})$, and thick STSGs (0.45 to $0.6 \mathrm{~mm})$ [18]. The different thickness layers are displayed in Figure 1.

In 1970, Janzekovic demonstrated her concept of early excision and wound coverage with autologous split-thickness skin grafts [19]. This method is considered as the current gold standard in surgical burn treatment, even today [4,5]. A major advantage of split-thickness skin grafting is the possibility of using the same donor site repeatedly after healing, which typically occurs within 7-14 days [20,21]. Further benefits are less morbidity and less scar formation in donor sites, which increase the contemplable donor sites, compared with full-thickness skin grafts [22]. Commonly used donor sites are thighs, legs, abdomen, back, arms, forearms, and chest [22,23]. In extensive burns, with a lack of eligible skin, the scalp or even scrotum can be used as last resort donor sites [24-27]. A 
distinction must be made between unmeshed STSGs (sheet grafts) and STSGs extended by specifically expanding methods. Sheet grafts are commonly used for small burns, while meshed split-thickness skin grafting depicts the best alternative for the coverage of large burns $[23,28,29]$.

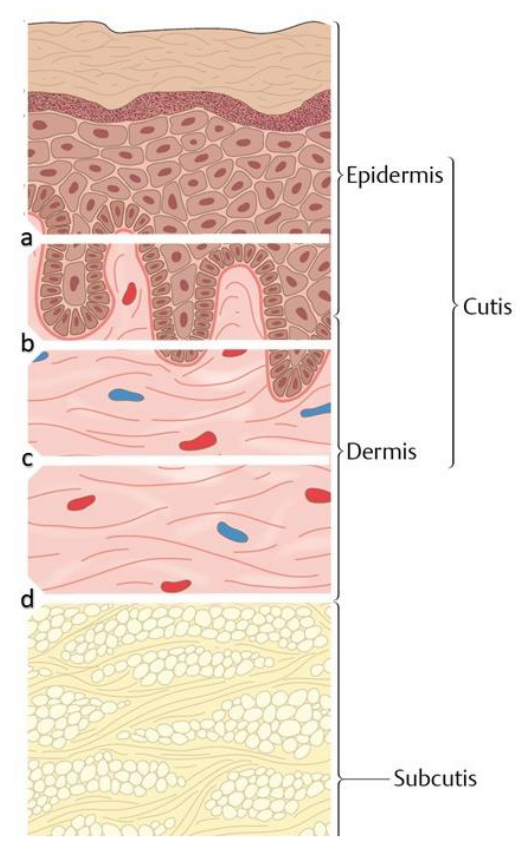

Figure 1. The classification of split thickness skin grafts $(\mathbf{a}-\mathbf{c})$ and full thickness skin graft (d) according to the thickness of the layer. $\mathrm{a}=0.15-0.3 \mathrm{~mm} ; \mathrm{b}=0.3-0.45 \mathrm{~mm} ; \mathrm{c}=0.5-0.6 \mathrm{~mm} ; \mathrm{d}>0.6 \mathrm{~mm}$.

\subsection{Sheet Graft}

Sheet grafting is considered to be the gold standard for the treatment of small burns and to cover sensitive areas $[5,28,30]$. Sheet grafts accelerate the end of the inflammatory phase and offer a better vascularization and re-innervation. Further benefits are the lower tendency for scar formation and contractures, a better aesthetic outcome, and no permanent mesh pattern in contrast to meshed skin grafts. Therefore, sheet grafts are appropriate to cover visible and functionally important areas [28,30]. Sheet grafts can as well be used to cover aesthetic and functional important areas in severe burns, in order to save donor sites instead of initial coverage with full-thickness skin grafts [31]. The disadvantages of sheet grafting are the need of larger donor sites, the risk of hematoma formation, the danger of losing the graft because of its impermeability, and the inability to cover severe burns, which is caused by a lack of donor sites [28].

\subsection{Mesh Graft}

Professor Otto Lanz was dissatisfied with the fact that the donor site of a Thiersch graft was still an open wound, while the initial defect already healed. He investigated various methods, but none of the experiments led to a satisfactory result. Due to a childhood game, which was used to build a paper accordion, he was encouraged to use the same method for skin grafting. Lanz developed an accordion-like expansion of a Thiersch graft in 1908, which not only served the purpose of covering the defect but also the newly formed wound of the donor site [32].

In 1964, James C. Tanner, a plastic surgeon at the Long Memorial Hospital, Atlanta developed a new method to produce expanded STSGs by usage of a new device named "Tanner-Vandeput mesh dermatome". By rolling split-thickness skin grafts through the novel dermatome, the machine cuts the skin grafts into a mesh with ribbons of skin 0.050-inches wide. Tanner's mesh grafting enabled skin grafts expanding up to a ratio $1: 3$, reducing the area of the donor site and offering the possibility of covering more 
wound area [33]. Nowadays, ratios up to $1: 6$ or even 1:9 are possible by using special devices [23]. Complete wound coverage can be achieved in approximately 10 days through rapid epithelialization in the absence of infection. Furthermore, a drainage of exudate and hemorrhage, as well regaining of areas lost by shrink is possible, due to the mesh-like structures. These properties are ideal for the treatment of burn injuries and large defects with limited donor sites $[34,35]$. The advantage of fluid drainage and a similar cosmetic outcome as with sheet grafts is achievable with a meshing ratio of 1:1 [28]. Additionally, mesh grafting shows a high percentage of graft take and enables covering large wound areas. Further benefits are the decrease of operating time and the reduction of the required number of necessary surgeries to achieve full rehabilitation.

Due to the advantages described above, the mesh skin graft method is well established and is considered as the standard method to surface large areas in severe burn treatment, even today $[4,5,23,36]$.

\subsection{Meek Technique}

In 1958 Cicero Parker Meek, a general practitioner at the Aiken Country Hospital in South Carolina known for his great interest in burn care, published an article called "Successful microdermagrafing using the Meek-Wall microdermatome". The Meek-Wall microdermatome consisted of 13 blades driven by an electronic engine. Flat cork plates served as carriers for the skin grafts $[37,38]$. The functions were described by a case report of a 14-year-old burn victim with $25 \%$ total body surface area. Meek cut conventional splitthickness skin grafts $\left(0.0125\right.$ inches) into units $1 / 16$ inches square $\left(40 \mathrm{~mm}^{2}\right)$. Subsequently, the microdermagrafts were saturated in plasma and evenly distributed to prefold parachute silk bandages, which were placed directly on the wound. After ten days, the grafted areas could be left exposed [37]. Meek's microdermal grafting enabled the possibility of covering large denuded areas after severe burns successfully by widely expanded stamp autografts [39]. In 1965, Meek published another article to describe his method step by step in detail and reported about the experience he made with the Meek-Wall dermatome [40]. The Meek technique was slowly forgotten after the development of the mesh grafting technique by Tanner in 1964. In the early 1990s, Meek's technology was rediscovered and improved by Dutch surgeons at the burn unit of the Red Cross Hospital in Beverwijk. The Meek technique was used successfully in the treatment of severe burns, when insufficient suitable donor sites were available for wound coverage with mesh grafts only. The clinical results of this modified Meek technique were first published by Kreis et al. in 1993 [41]. Thenceforth, the Meek technique returned in the clinical setting. The usage of the Meek technique offers many advantages, especially in the treatment of severe burns, which are often affected by the lack of donor sites. The Meek technique enabled an expansion of surface area coverage from 1:3 up to 1:9. The micro grafts allow a shorter duration and more uniform epithelialization than other techniques. Another benefit is the easy application compared to the difficult handling of higher expanded mesh grafts (1:6 or 1:9) [42-46]. In shortage of donor sites, Meek enabled the expansion of smaller grafts, as well the usage of donor sites, which cannot be grabbed by other grafting techniques [46,47]. Furthermore, the re-epithelialization time seems to be shorter with the Meek technique compared to mesh grafts [43]. Some graft takes failed by contamination, but these were mostly restricted to a partial area without affecting nearby skin islands $[42,48]$, while the observed total take rate with Meek grafts was described by several authors between $82.3 \%$ and $90 \%[42,44,45,48-50]$. Major disadvantages of Meek's method are the protracted procedure as well the necessity of more staff in the operating theater $[42,45]$.

\section{The Full-Thickness Skin Graft}

If the skin graft includes the entire thickness of the dermis, the appropriate term is full-thickness skin graft (FTSG) [51,52]. Full-thickness skin grafts are not widely used for emergency burn care but are ideal for the reconstruction after initial treatment and for scar corrections $[31,53]$. 
The first known full-thickness skin graft technique was presented by John Reissberg Wolfe in 1875. Wolfe described the correction of an ectropium by using a full-thickness skin graft after cutting accurately to the shape of the defect. A similar technique was described by Georg Lawson in 1870 and 1871, even though his name is not associated with the development of the full-thickness skin graft [7,54,55]. Fedor Krause, a German surgeon based in Hamburg, established the usage of full-thickness skin grafts. At the XXIII Congress of the German Surgical Association in 1893, Krause advised the usage of the Wolfe graft for all cases, where the Thiersch graft showed unsatisfactory outcomes and reported 21 cases in which full-thickness skin grafts were successfully transplanted. Krause's knowledge was well received not only nationally but also internationally, and the full-thickness graft achieved great popularity [6].

Nowadays, FTSGs are considered to achieve best results in burn deformity reconstructions due to less scar formation, good plasticity, elasticity, mobility, and aesthetic outcome, as well due to providing improved texture and color matching. After a long-term period, full-thickness skin grafts are almost similar to intact skin. Especially facial and palmar burns are one of the most challenging problems in burn injury treatment, but they are also a burden to the individual's psychological sentiment by functional disorders, structural defects, scars formation, scar contractures, as well soft tissue or hard tissue defects [56,57]. Hand burns often affect children in particular, leading to scar contracture and resulting in functional implications and disturbed evolution of the child's hand [22]. Full-thickness skin grafts are able to achieve excellent results in reconstruction, are aesthetically as well functionally superior to those obtained from sheet grafts, and therefore are the ideal choice for treatment of facial and palmar defects and scars suffered by burns [53,56-58]. Despite this occurrence of excellent results, various influencing factors must be observed by the performing surgeon at the selection of the eligible donor site: skin quality, skin color, texture, damage due to ultraviolet radiation, skin thickness, convenience, size, possibility of contractility, and scar formation after graft taking, as well the fact that donor sites can only be harvested once [53]. Summarizing, the usage of FTSGs achieves better aesthetic and functional results compared with STSGs. However, FTSGs have various limitations; thus, their usage should be reserved for the reconstruction of late deformities, especially in sensitive areas.

\section{Allogeneic and Xenogeneic Transplants}

The earliest proposals using foreign human skin or animal skin for burn injuries date back to the 19th century, but these failed [12,13,59-61]. Nevertheless, the first successes occurred not until the middle of the 20th century [31,62]. Even these days, allografts, usually taken by cadaver and xenografts, mostly from porcine skin, are used as temporary skin substitutes ahead to final coverage with autologous skin grafting, which provides a temporary coverage for up to 14 days, followed by the immunoreaction and rejection $[5,63]$. Currently, two common types of foreign skin are available, cryo-preserved or glycerol-preserved allografts [64]. Both preservation procedures have shown different benefits. While cryopreserved allografts demonstrated a better tissue viability, the glycerol preservation is cost-efficient, can reduce the antigenicity, and leads to longer storage periods [65-68].

The usage of porcine skin as a temporary wound dressing became popular in the 1960s, and it is still the most commonly used xenograft [62]. The major advantages of porcine skin include its easy availability and histopathological similarity to human skin [69,70]. Novel approaches are the usage of fish skin as a temporary biological dressing [71-73]. Alam and Jeffery demonstrated complete re-epithelialization in the absence of infection or adverse reaction in a case series of 10 patients with partial thickness burns treated with fish skin [72]. Bruno et al. presented Nile Tilapia fish skin as an easily available and cost-effective option as a xenograft [73]. A phase II randomized controlled trial showed that patients treated with Nile Tilapia fish skin had a statistically significant reduction of the mean time for re-epithelialization, significant pain reduction, and lower requirement of dressing changes compared with patients under silver sulfadiazine treatment [71]. According to these 
findings, fish skin seems to be a promising candidate as an effective and low-cost biological dressing for burn treatment, especially in middle- to low-income countries. However, for the introduction into the hospital setting, further investigations need to be done.

\section{Sandwich Technique}

Another option for the treatment of extensive loss of skin is the combined application of autologous STSGs and allografts. In 1981, Alexander et al. first publicized the successful usage of widely meshed autologous split-thickness skin grafts (1:6), which were overlayed by meshed allogeneic skin grafts (ratio 1:2) [74]. Although the usage of widely expanded mesh grafts has shown a bad outcome, the dressing with allografts enabled this method for the treatment of extensive burns, despite the lack of donor sites [74-76]. Good clinical results and a high rate of re-epithelization were achieved with the sandwich technique $[74,77]$.

\section{A Brief History of Skin Substitutes and Their Use Today}

Despite the great achievements of the expansion methods of Tanner and Meek, the treatment of extensive burns still presents crucial problems. Due to insufficient amounts of healthy native skin during the acute phase, an initial coverage with autologous skin is sometimes not possible. Therefore, several methods were developed over the past years to handle the absence of donor sites.

\subsection{Cell Cultures}

The first published formation of epidermis-like tissue by in vitro cultivation of human epidermal keratinocytes was performed by Rheinwald and Green in 1975 [78]. Ten years later, the first usage of human cultured epidermal autografts (CEAs) in a clinical case series were performed in 1980 by Connor et al [79]. Nowadays, the usage of CEAs is reserved for extensive burn injuries as a last resort opportunity when significantly less donor sites are remaining and other alternatives are not applicable. However, the application of CEAs is extremely time-consuming; these grafts are very fragile and susceptible to shear forces, and they additionally have a higher rate of blistering and re-grafting requirement $[80,81]$. A novel approach in the wound closure of extensive burned patients is the conjunction of CEAs with split-thickness skin grafting using high expansion techniques [82-84]. These methods enable the coverage of fragile body parts susceptible to pressure or shear forces with autologous STSGs, while insensitive areas can be covered with CEAs [82]. Another benefit is the reduction of donor sites [82,84]. Since 2007, cell therapies such as CEAs are considered as "Advanced Therapy Medicinal Products" (ATMP) by European Directives along with associated Regulations by the European Parliament. The aim of this adaption was to improve the safety and efficiency of cell therapy by standardization. Due to these new regulations, cell cultures need to be accomplished in an approved laboratory, along with new quality inspection measures and complex pathways, which the medical practitioner has to assess before deciding if a technique should be introduced [85]. Furthermore, the compliance of Good Manufacturing Practice requirements, as well the marketing authorization, for cell therapy production in hospital settings leads to higher costs [86]. Although it is important to ensure the safety for burn patients, these changes present a major challenge for clinical research not only in burn care but also in other cell research facilities in the hospital settings [85]. Gardien et al. showed the possibility of conducting a multicenter clinical trial that follows all requirements consistent with the ATMP guidelines [87].

\subsection{Dermal Substitutes}

In the last decades, burn care research has shifted from pure survival to a better quality of survival by focusing on improvement of the scars outcome and contractures prevention. Better functional and aesthetical results can be achieved through the use of dermal substitutes during the acute phase of burns [88]. Therefore the gain in importance 
of alloplastic or mixed synthetic-biological carriers with different alloplastic materials as dermal substitutes were observed in recent decades.

The first dermal analoga called "Integra ${ }^{\circledR}$ " was developed in the 1980s by Yannas and Burke as an alternative burn injury treatment $[89,90]$. Integra ${ }^{\circledR}$ consists of a dermal layer of bovine collagen and chondroitin-6-sulfate glycos-aminoglycan (GAG), as well an epidermal layer of silicone, and it was designed for the treatment of fresh excised fullthickness burns. The silicone layer has to be removed and replaced by a split-thickness skin graft after 2 or 3 weeks [91,92]. Aesthetic and functional results similar to healthy skin can be achieved in burned hands treated with Integra ${ }^{\circledR}$ and STSGs $[93,94]$. Currently, Integra ${ }^{\circledR}$ represents the most accepted artificial skin substitute due to favorable long-term use and outcomes $[88,91,92]$. Recently, a single layer version of Integra ${ }^{\circledR}$ was developed. The aim of this single layer version was to enable a one-step procedure with the simultaneous application of autologous STSGs [95]. However, further studies are necessary to establish an Integra ${ }^{\circledR}$ single layer in burn care.

Another option is the treatment with Matriderm ${ }^{\circledR}$, a single layer dermal substitute, which consists of a collagen-based matrix and allows a one-step procedure in combination with an autologous split-thickness skin graft as an alternative for the missing epidermal layer $[96,97]$. The use of Matriderm ${ }^{\circledR}$ in the treatments of burns in aesthetic and functional important areas achieved good results. Two studies by Ryssel et al. demonstrated an improved skin quality and range of motion in full-thickness burns of the hand's dorsum treated with STSGs and Matriderm ${ }^{\circledR}$ compared with ones treated by STSGs alone $[98,99]$. Furthermore, Matriderm ${ }^{\circledR}$ is useful for the treatment of facial burns $[96,100]$. According to Jackson and Roman, the combination of Matriderm ${ }^{\circledR}$ with split-thickness skin grafts is a safe and effective method to achieve better aesthetic and functional results in full-thickness facial burns [96].

Hyaluronic acid-based wound dressings were also introduced as an alternative for the dermal layer. Hyaluronic acid has a supportive role in the healing process, such as the stimulation of epidermal cell proliferation and migration, as well the promotion of fibroblast differentiation into myofibroblasts. Furthermore, hyaluronic acid improves the re-epithelization and granulation [101,102]. Hyalomatrix ${ }^{\circledR}$ was designed as a temporary dressing in cases of deep burns and full-thickness wounds for wound bed preparation prior to definitive coverage with STSGs [103-105]. Faga et al. demonstrated that the application of STSGs followed by Hyalomatrix ${ }^{\circledR}$ supports the dermis regeneration. The long-term biopsies showed that the regenerative skin was similar to healthy skin [106]. Gravante et al. even described that the aesthetic long-term result of patients treated with Hyalomatrix ${ }^{\circledR}$ were similar to those treated with the combination of STSGs and Hyalomatrix ${ }^{\circledR}$ [103].

In conclusion, the introduction of dermal substitutes led to burn care innovations, which enabled better functional and aesthetic outcomes. A major disadvantage is the dependence of the application of native skin. Future perspectives include the development of skin substitutes that are able to replace the dermal and the epidermal layer.

\subsection{Cell Suspension}

In 1895, Mangold described the first successful clinical application of scraped epithelial cells, which are known as a precursor of keratinocyte suspensions in modern burn care nowadays [107]. However, the technology was not able to be implemented due to the lack of an eligible carrier substance. Hunyadi et al. performed the first successful suspension of uncultured keratinocytes fixed on a fibrin carrier to treat chronic wounds in 1987 [108]. Nowadays, ReCell ${ }^{\circledR}$ is a common method for the preparation of non-cultured autologous cells by the isolation of cells from a small donor site and immediate autologous replantation by spraying to promote the healing process. ReCell ${ }^{\circledR}$ shows similar aesthetic results as STSGs and achieves an expansion ratio up to 1:80 [109-111]. The major benefit is the reduction of required donor sites for the treatment of high skin losses in severe burns [109111]. However, the procedure is very time-consuming, which leads to greater surgical stress for the patients and additional surgery costs [110]. 


\section{The Curse of Donor Site Morbidity}

Donor site morbidity is a considerable problem in surgery burn care that has attracted attention in recent years. Despite the advantages of split-thickness skin grafting, the harvesting of donor sites creates secondary injuries. These injuries need wound care and can be associated with donor site morbidities such as pain, pruritus, wound infection, and hyperpigmentation as well unaesthetic and unpleasant hypertrophic scars [112,113]. While morbidities such as pain and scars are common, the infection rate seems to be low [113]. Almost no findings are available on the prevalence of hypertrophic scars associated with donor site $[114,115]$. According to retrospective analyses, $34 \%$ of reviewed patients were affected by persistent hypertrophic scarring [114]. Karlsson et al. demonstrated that $28 \%$ of the patients in a randomized longitudinal clinical trial had donor site hypertrophic scars [115]. However, scar formation seems to be a major problem for affected patients. In a cohort study, Legemate et al. evaluated the long-term scar quality of donor sites as stated by burn patients. Patients assessed the scar quality at 12 months after burn by using the Patient and Observer Scar Assessment Scale (POSAS) version 2.0. The patients' overall opinion of the donor site scars was conspicuously high. The overall PSOAS score was 3.2 (1-10), even 1 year after surgery [116].

The usage of techniques, such as regrafting of the donor site or minced skin grafting, is described to reduce donor-site morbidity. Regrafting of the donor site is based on taking a larger amount of skin to cover not only the initial defect but also the donor site [117-119]. Several studies described an acceleration in re-epithelization, an improved scar quality, less pain, and a better aesthetic outcome by regrafting the donor site [117-119]. According to Bradow et al., all remaining pieces of a split-thickness skin graft should be placed back to the donor site. They also supposed that patients with poor healing potential could benefit from additional skin harvesting just for regrafting [117]. However, not all patients seem to benefit from the regrafting procedure. Legemate et al. demonstrated a worse result of the regrafted part compared with a non-grafted part in a follow up control of a 26-year-old woman 12 months after regrafting. While the non-grafted part was only a little erythematous, the regrafted part showed an irregular surface and a mix of hypo- and hyperpigmentation [120].

The technique of minced skin grafting is based on the use of the exceeded split skin, remaining after the application at the regular recipient area. These leftovers are prepared with tissue scissors until they get pasty enough to be dispensed onto the donor site [121,122]. Several studies showed a better quality of healing in terms of re-epithelialization and pigmentation, as well in a reduction of hypertrophic scarring and pruritus [121-123].

In conclusion, the application of STSG leftovers seems to be a promising way for the donor site treatment to reduce unpleasant morbidities. Especially, patients expected to develop a donor site morbidity could benefit from such procedures. Overall, a risk-benefit analysis could be useful to decide which patients could benefit by such procedures and who might not. Another technique to reduce donor site morbidity is dermal grafting, which is described below $[124,125]$.

\section{The Dermis Graft-A Novel Approach}

Dermis grafting is a method to obtain a de-epithelialized split-thickness skin graft [124]. The technique of dermis grafting is based on the simultaneous harvesting of a purely dermal split-thickness graft from the same donor site after taking the standard split-thickness skin graft $[124,125]$. In this procedure, two grafts are obtained, and the dermis graft is always transferred to the recipient site, while the ordinary split-thickness skin graft can serve as an additional graft [125], or it can be used for donor site coverage [124]. Lindeford et al. observed no difference in the healing duration between the dermal grafts and standard split-thickness skin grafts [125]. According to Han et al., the dermis grafting is superior to the regular STSG technique not only due to the accelerated and improved healing of the donor site but also in terms of pigmentation, height, and vascularity at the recipient sites [124]. Altogether, dermal grafting is an interesting method, which enables obtaining 
two grafts from a single donor site to minimize the need of available skin in extended burns and to reduce donor site-associated morbidity.

\section{Conclusions}

Great achievements in the development of skin grafting were made, especially over the past 200 years. Many of them are still part of the current burn injury treatment. Nowadays, autologous split-thickness skin grafting is considered as the gold standard for the treatment of major traumatic loss of skin caused by burns. The development of expansion methods enables the coverage of large wound surfaces and increases the survival of severely burned patients. Additionally, to the survival of severe burns, the quality of survival, by preventing scars formation and contractures, is one of the main goals in burn injuries management. A more cosmetic and functional result can be obtained by the usage of full-thickness skin grafts in reconstruction. However, autologous skin grafting is limited by available donor sites, especially in the initial treatment of severely burned patients. Historically, various attempts were already made to reproduce the properties of healthy skin to fill this gap. Significant progresses were made in the development of skin substitutes, which are a great discovery and fulfill their purpose in the burn injuries treatment. However, commonly used skin substitutes are not able to achieve the properties of native skin. Almost all products are only able to replace one: the epidermal or dermal skin layers. As a current challenge, donor site morbidity, such as wound infection, hyperpigmentation, and hypertrophic scarring attract attention. Several approaches were already made to solve this problem. However, further investigations are needed. The long-term objective is the development of novel methods or combined techniques allowing covering large burn surfaces without the necessity of high amounts of donor sites. In summary, the desired result has not been achieved, and despite several drawbacks, autologous skin grafting remains the method of choice for burn coverage, even more than 3000 years after its discovery.

Limitations: This review has some inherent limitations. Many of the original articles are not written in the English language or are not available through the online database, which is caused by the fact that they are even older than the internet. Therefore, the content of this review is reliant on reprints and biographical literature. Finally, our review is limited to articles retrieved from PubMed and Google Scholar only with the possibility of missed publications.

Author Contributions: Conceptualization, Methodology, and Data Acquisition, M.K.; WritingOriginal Draft Preparation, M.K.; Review and Editing, H.L. and S.P.N.; Supervision, L.P.K. All authors have read and agreed to the published version of the manuscript.

Funding: This research received no external funding.

Institutional Review Board Statement: Ethical review and approval were waived caused by exclusive use of data from the literature.

Informed Consent Statement: Patient consent was not necessary due to exclusive use of data from the literature.

Data Availability Statement: No new data were created or analyzed due to this study. Data sharing is not applicable to this article.

Conflicts of Interest: All authors declare no conflict of interest.

\section{References}

1. Church, D.; Elsayed, S.; Reid, O.; Winston, B.; Lindsay, R. Burn Wound Infections. Clin. Microbiol. Rev. 2006, 19, 403-434. [CrossRef]

2. Sorg, H.; Tilkorn, D.J.; Hager, S.; Hauser, J.; Mirastschijski, U. Skin Wound Healing: An Update on the Current Knowledge and Concepts. Eur. Surg. Res. 2017, 58, 81-94. [CrossRef]

3. Brusselaers, N.; Pirayesh, A.; Hoeksema, H.; Richters, C.D.; Verbelen, J.; Beele, H.; Blot, S.I.; Monstrey, S. Skin Replacement in Burn Wounds. J. Trauma Inj. Infect. Crit. Care 2010, 68, 490-501. [CrossRef] [PubMed] 
4. Jeschke, M.G.; Shahrokhi, S.; Finnerty, C.C.; Branski, L.K.; Dibildox, M. Wound Coverage Technologies in Burn Care: Established Techniques. J. Burn. Care Res. 2018, 39, 313-318. [CrossRef] [PubMed]

5. Jeschke, M.G.; Van Baar, M.E.; Choudhry, M.A.; Chung, K.K.; Gibran, N.S.; Logsetty, S. Burn injury. Nat. Rev. Dis. Prim. 2020, 6, 11. [CrossRef] [PubMed]

6. Ehrenfried, A. Reverdin and Other Methods of Skin-Grafting: Historical. Boston Med Surg. J. 1909, 161, 911-917. [CrossRef]

7. Ang, G.C. History of skin transplantation. Clin. Dermatol. 2005, 23, 320-324. [CrossRef]

8. Hauben, D.J.; Baruchin, A.; Mahler, A. On the History of the Free Skin Graft. Ann. Plast. Surg. 1982, 9, 242-245. [CrossRef]

9. Hattery, E.; Nguyen, T.; Baker, A.; Palmieri, T. Burn Care in the 1800s. J. Burn. Care Res. 2015, 36, 236-239. [CrossRef]

10. McDowell, F. Successful attempt of reconstruction of a nose from a completely separated piece of skin from the leg, by Prof. Dr. Bünger, Marburg, Germany. (Journal der Chirurgie and Augenheilkunde, 4: 569, 1822). Translated from the German by Dr. Hans May. Plast. Reconstr. Surg. 1969, 44, 486-490.

11. Fariña-Pérez, L.A. Jaques-Louis Reverdin (1842-1929): The surgeon and the needle. Arch. Esp. Urol. 2010, 63, 269-274. [CrossRef]

12. Freshwater, M.F.; Krizek, T.J. Skin grafting of burns: A centennial. A tribute to George David Pollock. J. Trauma 1971, 11, 862-865. [CrossRef]

13. Freshwater, M.F.; Krizek, T.J. George David Pollock and the Development of Skin Grafting. Ann. Plast. Surg. 1978, 1, 96-102. [CrossRef]

14. Rogers, B.O. Historical Development of Free Skin Grafting. Surg. Clin. N. Am. 1959, 39, 289-311. [CrossRef]

15. McDowell, F. Carl Thiersch, microscopy, and skin grafting. Plast. Reconstr. Surg. 1968, 41, 369-370. [PubMed]

16. Blair, V.P.; Brown, J.B. The use and uses of large split skin grafts of intermediate thickness. Plast. Reconstr. Surg. 1968, 42, 65-75. [CrossRef]

17. Padgett, E.C. Skin grafting and the "three-quarter"-thickness skin graft for prevention and correction of cicatricial, formation. Ann. Surg. 1941, 113, 1034-1049. [CrossRef] [PubMed]

18. Braza, M.E.; Fahrenkopf, M.P. Split-Thickness Skin Grafts; StatPearls Publishing: Treasure Island, FL, USA, 2021. [PubMed]

19. Janzekovic, Z. A new concept in the early excision and immediate grafting of burns. J. Trauma 1970, 10, 1103-1108. [CrossRef] [PubMed]

20. Barret, J.P.; Dziewulski, P.; Wolf, S.E.; Desai, M.H.; Nichols, R.J.; Herndon, D.N. Effect of topical and subcutaneous epinephrine in combination with topical thrombin in blood loss during immediate near-total burn wound excision in pediatric burned patients. Burns 1999, 25, 509-513. [CrossRef]

21. Masella, D.P.C.; Balent, E.M.; Carlson, D.T.L.; Lee, B.K.W.; Pierce, D.L.M. Evaluation of Six Split-thickness Skin Graft Donor-site Dressing Materials in a Swine Model. Plast. Reconstr. Surg. 2013, 1, 1-11. [CrossRef]

22. Chan, Q.E.; Barzi, F.; Harvey, J.G.; Holland, A.J.A. Functional and Cosmetic Outcome of Full- Versus Split-Thickness Skin Grafts in Pediatric Palmar Surface Burns: A prospective, independent evaluation. J. Burn. Care Res. 2013, 34, 232-236. [CrossRef]

23. Pripotnev, S.; Papp, A. Split thickness skin graft meshing ratio indications and common practices. Burns 2017, 43, 1775-1781. [CrossRef] [PubMed]

24. Van Niekerk, G.; Adams, S.; Rode, H. Scalp as a donor site in children: Is it really the best option? Burns 2018, 44, 1259-1268. [CrossRef] [PubMed]

25. Mimoun, M.; Chaouat, M.; Picovski, D.; Serroussi, D.; Smarrito, S. The Scalp Is an Advantageous Donor Site for Thin-Skin Grafts: A Report on 945 Harvested Samples. Plast. Reconstr. Surg. 2006, 118, 369-373. [CrossRef] [PubMed]

26. Desai, M.H.; Herndon, D.N.; Rutan, R.L.; Parker, J. An Unusual Donor Site, a Lifesaver in Extensive Burns. J. Burn Care Rehabil. 1988, 9, 637-639. [CrossRef]

27. Wyrzykowski, D.; Chrzanowska, B.; Czauderna, P. Ten years later-Scalp still a primary donor site in children. Burns 2015, 41, 359-363. [CrossRef]

28. Nikkhah, D.; Booth, S.; Tay, S.; Gilbert, P.; Dheansa, B. Comparing outcomes of sheet grafting with 1:1 mesh grafting in patients with thermal burns: A randomized trial. Burns 2015, 41, 257-264. [CrossRef]

29. Greenhalgh, D.G. Management of burns. N. Engl. J. Med. 2019, 380, 2349-2359. [CrossRef]

30. Archer, S.B.; Henke, A.; Greenhalgh, D.G.; Warden, G.D. The Use of Sheet Autografts to Cover Extensive Burns in Patients. J. Burn. Care Rehabil. 1998, 19, 33-38. [CrossRef]

31. Brown, J.B.; McDowell, F. Massive repairs of burns with thick split-skin grafts: Emergency dressings with homografts. Ann. Surg. 1942, 115, 658-674. [CrossRef]

32. Clodius, L. The classic reprint. Die Transplantation Betreffend by Prof. Otto Lanz. Plast. Reconstr. Surg. 1972, 50, 395-397. [PubMed]

33. Tanner, J.C.; Vandeput, J.; Olley, J.F. The mesh skin graft. Plast. Reconstr. Surg. 1964, 34, 287-292.

34. Tanner, J.C.; Vandeput, J.J.; Bradley, W.H. Mesh skin grafting: Report of a typical case. J. Occup. Med. 1965, 7, 175-176. [CrossRef] [PubMed]

35. Salisbury, R.B. Use of the Mesh Skin Graft in Treatment of Massive Casualty Wounds. Plast. Reconstr. Surg. 1967, 40, 161-162. [CrossRef] [PubMed]

36. Macmillan, B.G. The Use of Mesh Grafting in Treating Burns. Surg. Clin. N. Am. 1970, 50, 1347-1359. [CrossRef]

37. Meek, C.P. Successful microdermagrafting using the Meek-Wall microdermatome. Am. J. Surg. 1958, 96, 557-558. [CrossRef]

38. Ottomann, C.; Hartmann, B.; Branski, L.; Krohn, C. A tribute to Cicero Parker Meek. Burns 2015, 41, 1660-1663. [CrossRef]

39. Meek, C.P. Medical Debridement and Microdermagrafting of Burns. South. Med J. 1963, 56, 1074-1076. [CrossRef] 
40. Meek, C.P. Microdermagrafting: The Meek technic. Hosp. Top. 1965, 43, 114-116. [CrossRef]

41. Kreis, R.; Mackie, D.; Vloemans, A.; Hermans, R.; Hoekstra, M. Widely expanded postage stamp skin grafts using a modified Meek technique in combination with an allograft overlay. Burns 1993, 19, 142-145. [CrossRef]

42. Lumenta, D.B.; Kamolz, L.-P.; Frey, M. Adult Burn Patients With More Than 60\% TBSA Involved-Meek and Other Techniques to Overcome Restricted Skin Harvest Availability-The Viennese Concept. J. Burn. Care Res. 2009, 30, 231-242. [CrossRef] [PubMed]

43. Dahmardehei, M.; Vaghardoost, R.; Saboury, M.; Zarei, H.; Saboury, S.; Molaei, M.; Seyyedi, J.; Maleknejad, A.; Hospital, I.F. Comparison of Modified Meek Technique with Standard Mesh Method in Patients with Third Degree Burns. World J. Plast. Surg. 2020, 9, 267-273. [CrossRef] [PubMed]

44. Lee, S.Z.; Halim, A.S.; Sulaiman, W.A.W.; Saad, A.Z.M. Outcome of the Modified Meek Technique in the Management of Major Pediatric Burns. Ann. Plast. Surg. 2018, 81, 295-301. [CrossRef] [PubMed]

45. Lari, A.R.; Gang, R.K. Expansion technique for skin grafts (Meek technique) in the treatment of severely burned patients. Burns 2001, 27, 61-66. [CrossRef]

46. Wanjala, N.F.; Paul, O.J.; Sephania, O.R. Meek Micro-grafting Technique in Reduction of Mortality and Hospital Stay in Patients with Extensive Burns in a Resource Constrained Setting. J. Surg. 2018, 6, 154. [CrossRef]

47. Sánchez-García, A.; Vanaclocha, N.; García-Vilariño, E.; Salmerón-González, E.; Vicente-Pardo, A.; Pérez-Del Caz, M.D. Use of the Meek Micrografting Technique for Coverage of Extensive Burns: A Case Report. Plast. Surg. Nurs. 2019, 39, 44-47. [CrossRef]

48. Houschyar, K.S.; Tapking, C.; Nietzschmann, I.; Rein, S.; Weissenberg, K.; Chelliah, M.P.; Duscher, D.; Maan, Z.N.; Philipps, H.M.; Sheckter, C.C.; et al. Five Years Experience With Meek Grafting in the Management of Extensive Burns in an Adult Burn Center. Plast. Surg. 2018, 27, 44-48. [CrossRef]

49. Lee, S.Z.; Halim, A.S. Superior long term functional and scar outcome of Meek micrografting compared to conventional split thickness skin grafting in the management of burns. Burns 2019, 45, 1386-1400. [CrossRef]

50. Munasinghe, N.; Wasiak, J.; Ives, A.; Cleland, H.; Lo, C.H. Retrospective review of a tertiary adult burn centre's experience with modified Meek grafting. Burn. Trauma 2016, 4, 6. [CrossRef]

51. Kilner, T.P. The Full-Thickness Skin Graft. Postgrad. Med J. 1935, 11, 279-282. [CrossRef]

52. Padgett, E.C. Indications for determination of the thickness of split skin grafts. Am. J. Surg. 1946, 72, 683-693. [CrossRef]

53. Çeliköz, B.; Deveci, M.; Duman, H.; Nişanci, M. Recontruction of facial defects and burn scars using large size freehand full-thickness skin graft from lateral thoracic region. Burns 2001, 27, 174-178. [CrossRef]

54. Somma, A.M.; Somma, L.M. John Reissberg Wolfe (1823-1904): A plastic surgeon in Garibaldi's Army. J. Med Biogr. 2010, 18, 77-80. [CrossRef] [PubMed]

55. Sykes, P.J. Wolfe's Part in the Italian Risorgimento and His Skin Graft. Ann. Plast. Surg. 2012, 69, 228-231. [CrossRef] [PubMed]

56. Bogdanov, S.B.; Gilevich, I.V.; Melkonyan, K.I.; Sotnichenko, A.S.; Alekseenko, S.N.; Porhanov, V.A. Total full-thickness skin grafting for treating patients with extensive facial burn injury: A 10-year experience. Burns 2020. [CrossRef]

57. Weeks, D.; Kasdan, M.L.; Wilhelmi, B.J. Forty-Year Follow-up of Full-Thickness Skin Graft After Thermal Burn Injury to the Volar Hand. Eplasty 2016, 16, e21.

58. Merrell, S.W.; Saffle, J.R.; Schnebly, W.A.; Kravitz, M.; Warden, G.D. Full-Thickness Skin Grafting for Contact Burns of the Palm in Children. J. Burn. Care Rehabil. 1986, 7, 501-507. [CrossRef]

59. Seghers, M.J.; Longacre, J.J. Paul Bert and his animal grafts. Plast. Reconstr. Surg. 1964, 33, 178-186. [CrossRef]

60. Cooper, D.K.; Ekser, B.; Tector, A.J. A brief history of clinical xenotransplantation. Int. J. Surg. 2015, 23 Pt B, 205-210. [CrossRef]

61. Bromberg, B.E.; Song, I.C.; Mohn, M.P. The use of pig skin as a temporary biological dressing. Plast. Reconstr. Surg. 1965, 36, 80-90. [CrossRef]

62. Yamamoto, T.; Iwase, H.; King, T.W.; Hara, H.; Cooper, D.K. Skin xenotransplantation: Historical review and clinical potential. Burns 2018, 44, 1738-1749. [CrossRef]

63. Rowan, M.P.; Cancio, L.C.; Elster, E.A.; Burmeister, D.M.; Rose, L.F.; Natesan, S.; Chan, R.K.; Christy, R.J.; Chung, K.K. Burn wound healing and treatment: Review and advancements. Crit. Care 2015, 19, 1-12. [CrossRef] [PubMed]

64. Wang, C.; Zhang, F.; Lineaweaver, W.C. Clinical Applications of Allograft Skin in Burn Care. Ann. Plast. Surg. 2020, 84, S158-S160 [CrossRef] [PubMed]

65. Blome-Eberwein, S.; Jester, A.; Kuentscher, M.; Raff, T.; Germann, G.; Pelzer, M. Clinical practice of glycerol preserved allograft skin coverage. Burns 2002, 28, 10-12. [CrossRef]

66. Hoekstra, M.J.; Kreis, R.W.; du Pont, J.S. History of the Euro Skin Bank: The innovation of preservation technologies. Burns 1994, 20, S43-S47. [CrossRef]

67. Hermans, M.H. Preservation methods of allografts and their (lack of) influence on clinical results in partial thickness burns. Burns 2011, 37, 873-881. [CrossRef]

68. Kua, E.H.J.; Goh, C.Q.; Ting, Y.; Chua, A.; Song, C. Comparing the use of glycerol preserved and cryopreserved allogenic skin for the treatment of severe burns: Differences in clinical outcomes and in vitro tissue viability. Cell Tissue Bank. 2012, 13, 269-279. [CrossRef] [PubMed]

69. Debeer, S.; Le Luduec, J.-B.; Kaiserlian, D.; Laurent, P.; Nicolas, J.-F.; Dubois, B.; Kanitakis, J. Comparative histology and immunohistochemistry of porcine versus human skin. Eur. J. Dermatol. 2013, 23, 456-466. [CrossRef] 
70. Sykes, D.S. Transplanting organs from pigs to humans Megan. Physiol. Behav. 2016, 176, 100-106. [CrossRef]

71. Júnior, E.M.L.; Filho, M.O.D.M.; Costa, B.A.; Rohleder, A.V.P.; Rocha, M.B.S.; Fechine, F.V.; Forte, A.J.; Alves, A.P.N.N.; Júnior, F.R.S.; Martins, C.B.; et al. Innovative Burn Treatment Using Tilapia Skin as a Xenograft: A Phase II Randomized Controlled Trial. J. Burn. Care Res. 2020, 41, 585-592. [CrossRef]

72. Alam, K.; Jeffery, S.L. Acellular Fish Skin Grafts for Management of Split Thickness Donor Sites and Partial Thickness Burns: A Case Series. Mil. Med. 2019, 184, 16-20. [CrossRef]

73. Costa, B.A.; Júnior, E.M.L. Use of Tilapia Skin as a Xenograft for Pediatric Burn Treatment: A Case Report. J. Burn Care Res. 2020, 40, 714-717. [CrossRef] [PubMed]

74. Alexander, J.W.; Macmillan, B.G.; Law, E.; Kittur, D.S. Treatment of severe burns with widely meshed skin autograft and meshed skin allograft overlay. J. Trauma 1981, 21, 433-438. [PubMed]

75. Phipps, A.R.; Clarke, J.A. The use of intermingled autograft and parental allograft skin in the treatment of major burns in children. Br. J. Plast. Surg. 1991, 44, 608-611. [CrossRef]

76. Qaryoute, S.; Mirdad, I.; Hamail, A. Usage of autograft and allograft skin in treatment of burns in children. Burns 2001, 27, 599-602. [CrossRef]

77. Horch, R.E.; Stark, G.; Kopp, J.; Spilker, G. Cologne Burn Centre experiences with glycerol-preserved allogeneic skin: Part I: Clinical experiences and histological findings (overgraft and sandwich technique). Burns 1994, 20, S23-S26. [CrossRef]

78. Rheinwatd, J.G.; Green, H. Serial cultivation of strains of human epidermal keratinocytes: The formation of keratinizing colonies from single cells. Cell 1975, 6, 331-343. [CrossRef]

79. O'Connor, N.; Mulliken, J.; Banks-Schlegel, S.; Kehinde, O.; Green, H. Grafting of burns with cultured epithelium prepared from autologous epidermal cells. Lancet 1981, 317, 75-78. [CrossRef]

80. Barret, J.P.; Wolf, S.E.; Desai, M.H.; Herndon, D.N. Cost-Efficacy of Cultured Epidermal Autografts in Massive Pediatric Burns. Ann. Surg. 2000, 231, 869-876. [CrossRef]

81. Matsumura, H.; Matsushima, A.; Ueyama, M.; Kumagai, N. Application of the cultured epidermal autograft "JACE ${ }^{\circledR}$ for treatment of severe burns: Results of a 6-year multicenter surveillance in Japan. Burns 2016, 42, 769-776. [CrossRef] [PubMed]

82. Ottomann, C.; Küntscher, M.V.; Hartmann, B. The Combination of Cultured Epidermal Autograft (CEA) and Split Thickness Skin Graft Technique (Meek) in Therapy for Severe Burns. Osteosynth. Trauma Care 2007, 15, 29-33. [CrossRef]

83. Menon, S.; Li, Z.; Harvey, J.G.; Holland, A.J. The use of the Meek technique in conjunction with cultured epithelial autograft in the management of major paediatric burns. Burns 2013, 39, 674-679. [CrossRef] [PubMed]

84. Akita, S.; Hayashida, K.; Yoshimoto, H.; Fujioka, M.; Senju, C.; Morooka, S.; Nishimura, G.; Mukae, N.; Kobayashi, K.; Anraku, K.; et al. Novel Application of Cultured Epithelial Autografts (CEA) with Expanded Mesh Skin Grafting Over an Artificial Dermis or Dermal Wound Bed Preparation. Int. J. Mol. Sci. 2018, 19, 57. [CrossRef] [PubMed]

85. Dimitropoulos, G.; Jafari, P.; de Buys Roessingh, A.; Hirt-Burri, N.; Raffoul, W.; Applegate, L.A. Burn patient care lost in good manufacturing practices? Ann. Burn. Fire Disasters 2016, 29, 111-115.

86. Abdel-Sayed, P.; Michetti, M.; Scaletta, C.; Flahaut, M.; Hirt-Burri, N.; Roessingh, A.D.B.; Raffoul, W.; Applegate, L.A. Cell therapies for skin regeneration: An overview of 40 years of experience in burn units. Swiss Med Wkly. 2019, 149, w20079. [CrossRef]

87. Gardien, K.L.M.; Marck, R.E.; Bloemen, M.C.T.; Waaijman, T.; Gibbs, S.; Ulrich, M.M.W.; Middelkoop, E. Outcome of Burns Treated with Autologous Cultured Proliferating Epidermal Cells: A Prospective Randomized Multicenter Intrapatient Comparative Trial. Cell Transplant. 2016, 25, 437-448. [CrossRef]

88. Arno, A.I.; Jeschke, M.G. The Use of Dermal Substitutes in Burn Surgery: Acute Phase. Dermal Replace. Gen. Burn Plast. Surg. Tissue Eng. Clin. Pr. 2014, 9783709115, 193-210. [CrossRef]

89. Yannas, I.V.; Burke, J.F. Design of an artificial skin. I. Basic design principles. J. Biomed. Mater. Res. 1980, 14, 65-81. [CrossRef]

90. Yannas, I.V.; Burke, J.F.; Gordon, P.L.; Huang, C.; Rubenstein, R.H. Design of an artificial skin. II. Control of chemical composition. J. Biomed. Mater. Res. 1980, 14, 107-132. [CrossRef]

91. Heimbach, D.M.; Warden, G.D.; Luterman, A.; Jordan, M.H.; Ozobia, N.; Ryan, C.M.; Voigt, D.W.; Hickerson, W.L.; Saffle, J.R.; Declement, F.A.; et al. Multicenter Postapproval Clinical Trial of Integra ${ }^{\circledR}$ Dermal Regeneration Template for Burn Treatment. J. Burn. Care Rehabil. 2003, 24, 42-48. [CrossRef]

92. Branski, L.K.; Herndon, D.N.; Pereira, C.; Mlcak, R.P.; Celis, M.M.; Lee, J.O.; Sanford, A.P.; Norbury, W.B.; Zhang, X.-J.; Jeschke, M.G. Longitudinal assessment of Integra in primary burn management: A randomized pediatric clinical trial. Crit. Care Med. 2007, 35, 2615-2623. [CrossRef] [PubMed]

93. Danin, A.; Georgesco, G.; Le Touze, A.; Penaud, A.; Quignon, R.; Zakine, G. Assessment of burned hands reconstructed with Integra ${ }^{\circledR}$ by ultrasonography and elastometry. Burns 2012, 38, 998-1004. [CrossRef]

94. Cuadra, Á.; Correa, G.; Roa, R.; Piñeros, J.L.; Norambuena, H.; Searle, S.; Heras, R.L.; Calderon, W. Functional results of burned hands treated with Integra ${ }^{\circledR}$. J. Plast. Reconstr. Aesthetic Surg. 2012, 65, 228-234. [CrossRef]

95. Koenen, W.; Felcht, M.; Vockenroth, K.; Sassmann, G.; Goerdt, S.; Faulhaber, J. One-stage reconstruction of deep facial defects with a single layer dermal regeneration template. J. Eur. Acad. Dermatol. Venereol. 2010, 25, 788-793. [CrossRef] [PubMed]

96. Jackson, S.R.; Roman, S. Matriderm and Split Skin Grafting for Full-Thickness Pediatric Facial Burns. J. Burn Care Res. 2019, 40, 251-254. [CrossRef] 
97. Phillips, G.S.A.; Nizamoglu, M.; Wakure, A.; Barnes, D.; Dziewulski, P. The use of dermal regeneration templates for primary burns surgery in a UK regional burns centre. Ann. Burn. Fire Disasters 2020, XXXIII, 245-252.

98. Ryssel, H.; Gazyakan, E.; Germann, G.; Öhlbauer, M. The use of MatriDerm ${ }^{\circledR}$ in early excision and simultaneous autologous skin grafting in burns-A pilot study. Burns 2008, 34, 93-97. [CrossRef]

99. Ryssel, H.; Germann, G.; Kloeters, O.; Gazyakan, E.; Radu, C. Dermal substitution with Matriderm ${ }^{\circledR}$ in burns on the dorsum of the hand. Burns 2010, 36, 1248-1253. [CrossRef]

100. Greenhalgh, D.G.; Hinchcliff, K.; Sen, S.; Palmieri, T.L. A Ten-Year Experience with Pediatric Face Grafts. J. Burn. Care Res. 2010, 34, 576-584. [CrossRef] [PubMed]

101. Graça, M.F.; Miguel, S.P.; Cabral, C.S.; Correia, I.J. Hyaluronic acid-Based wound dressings: A review. Carbohydr. Polym. 2020, 241, 116364. [CrossRef]

102. Longinotti, C. The use of hyaluronic acid based dressings to treat burns: A review. Burn. Trauma 2014, 2, 162-168. [CrossRef] [PubMed]

103. Gravante, G.; Sorge, R.; Merone, A.; Tamisani, A.M.; Di Lonardo, A.; Scalise, A.; Doneddu, G.; Melandri, D.; Stracuzzi, G.; Onesti, M.G.; et al. Hyalomatrix PA in Burn Care Practice: Results from a national retrospective survey, 2005 to 2006. Ann. Plast. Surg. 2010, 64, 69-79. [CrossRef]

104. Erbatur, S.; Coban, Y.K.; Aydın, E.N. Comparision of clinical and histopathological results of hyalomatrix usage in adult patients. Int. J. Burn. Trauma 2012, 2, 118-125.

105. Gravante, G.; Delogu, D.; Giordan, N.; Morano, G.; Montone, A.; Esposito, G. The Use of Hyalomatrix PA in the Treatment of Deep Partial-Thickness Burns. J. Burn. Care Res. 2007, 28, 269-274. [CrossRef] [PubMed]

106. Faga, A.; Nicoletti, G.; Brenta, F.; Scevola, S.; Abatangelo, G.; Brun, P. Hyaluronic acid three-dimensional scaffold for surgical revision of retracting scars: A human experimental study. Int. Wound J. 2013, 10, 329-335. [CrossRef] [PubMed]

107. Mangoldt, F. Die Epithelsaat zum Verschlußeiner großen Wundfläche. Med. Wochenschr 1895, 21, 798-903. [CrossRef]

108. Hunyadi, J.; Farkas, B.; Bertényi, C.; Oláh, J.; Dobozy, A. Keratinocyte Grafting: Covering of Skin Defects by Separated Autologous Keratinocytes in a Fibrin Net. J. Investig. Dermatol. 1987, 89, 119-120. [CrossRef] [PubMed]

109. Holmes, J.; Molnar, J.; Shupp, J.; Hickerson, W.; King, B.T.; Foster, K.; Cairns, B.; Carter, J. Demonstration of the safety and effectiveness of the RECELL ${ }^{\circledR}$ System combined with split-thickness meshed autografts for the reduction of donor skin to treat mixed-depth burn injuries. Burns 2019, 45, 772-782. [CrossRef] [PubMed]

110. Gravante, G.; Di Fede, M.; Araco, A.; Grimaldi, M.; De Angelis, B.; Arpino, A.; Cervelli, V.; Montone, A. A randomized trial comparing ReCell ${ }^{\circledR}$ system of epidermal cells delivery versus classic skin grafts for the treatment of deep partial thickness burns. Burns 2007, 33, 966-972. [CrossRef]

111. Iv, J.H.H.; Molnar, J.; Carter, J.; Hwang, J.; Cairns, B.; King, B.T.; Smith, D.J.; Cruse, C.W.; Foster, K.N.; Peck, M.D.; et al. A Comparative Study of the ReCell ${ }^{\circledR}$ Device and Autologous Split-Thickness Meshed Skin Graft in the Treatment of Acute Burn Injuries. J. Burn. Care Res. 2018, 39, 694-702. [CrossRef]

112. Otene, C.; Olaitan, P.B.; Ogbonnaya, I.S.; Nnabuko, R. Donor site morbidity following harvest of split-thickness skin grafts in south eastern nigeria. J. West Afr. Coll. Surg. 2016, 1, 86-96.

113. Asuku, M.; Yan, Q.; Yu, T.-C.; Boing, E.; Hahn, H.; Hovland, S.; Donelan, M.B. 522 Skin Graft Donor-site Morbidity: A Systematic Literature Review. J. Burn. Care Res. 2020, 41, S98-S99. [CrossRef]

114. Rotatori, R.M.; Starr, B.; Peake, M.; Fowler, L.; James, L.; Nelson, J.; Dale, E.L. Prevalence and Risk Factors for Hypertrophic Scarring of Split Thickness Autograft Donor Sites in a Pediatric Burn Population. Burns 2019, 45, 1066-1074. [CrossRef] [PubMed]

115. Karlsson, M.; Elmasry, M.; Steinvall, I.; Sjöberg, F.; Olofsson, P.; Thorfinn, J. Scarring At Donor Sites After Split-Thickness Skin Graft: A Prospective, Longitudinal, Randomized Trial. Adv. Ski. Wound Care 2018, 31, 183-188. [CrossRef]

116. Legemate, C.M.; Ooms, P.J.; Trommel, N.; Middelkoop, E.; van Baar, M.E.; Goei, H.; van der Vlies, C.H. Patient-reported scar quality of donor-sites following split-skin grafting in burn patients: Long-term results of a prospective cohort study. Burns 2021, 47, 315-321. [CrossRef] [PubMed]

117. Bradow, B.P.; Hallock, G.G.; Wilcock, S.P. Immediate Regrafting of the Split Thickness Skin Graft Donor Site Assists Healing. Plast. Reconstr. Surg. Glob. Open 2017, 5, e1339. [CrossRef]

118. Goverman, J.; Kraft, C.T.; Fagan, S.; Levi, B. Back Grafting the Split-Thickness Skin Graft Donor Site. J. Burn. Care Res. 2017, 38, e443-e449. [CrossRef]

119. Bian, Y.; Sun, C.; Zhang, X.; Li, Y.; Li, W.; Lv, X.; Li, J.; Jiang, L.; Li, J.; Feng, J.; et al. Wound-healing improvement by resurfacing split-thickness skin donor sites with thin split-thickness grafting. Burns 2016, 42, 123-130. [CrossRef]

120. Legemate, C.M.; Lucas, Y.; Oen, I.M.M.H.; Van Der Vlies, C.H. Regrafting of the Split-Thickness Skin Graft Donor-Site: Is It Beneficial? J. Burn. Care Res. 2020, 41, 211-214. [CrossRef]

121. Miyanaga, T.; Kishibe, M.; Yamashita, M.; Kaneko, T.; Kinoshita, F.; Shimada, K. Minced Skin Grafting for Promoting Wound Healing and Improving Donor-Site Appearance after Split-Thickness Skin Grafting: A Prospective Half-Side Comparative Trial. Plast. Reconstr. Surg. 2019, 144, 475-483. [CrossRef]

122. Kumar, P.; Ajai, K.S.; Sharma, R.K. The role of recruited minced skin grafting in improving the quality of healing at the donor site of split-thickness skin graft-A comparative study. Burns 2019, 45, 923-928. [CrossRef]

123. Miyanaga, T.; Haseda, Y.; Sakagami, A. Minced skin grafting for promoting epithelialization of the donor site after split-thickness skin grafting. Burns 2017, 43, 819-823. [CrossRef] [PubMed] 
124. Han, S.-K.; Yoon, T.-H.; Kim, J.-B.; Kim, W.-K. Dermis Graft for Wound Coverage. Plast. Reconstr. Surg. 2007, 120, 166-172. [CrossRef] [PubMed]

125. Lindford, A.J.; Kaartinen, I.S.; Virolainen, S.; Kuokkanen, H.O.; Vuola, J. The dermis graft: Another autologous option for acute burn wound coverage. Burns 2012, 38, 274-282. [CrossRef] [PubMed] 